\title{
KARAKTERISTIK DAN TINGKAT PENGETAHUAN IBU NIFAS TENTANG INISIASI MENYUSU DINI
}

\section{Characteristics and Level of Knowledge of Postpartum Mother about Early Initiation of Breastfeeding}

\author{
Kurnia $^{1}$ \\ ${ }^{1}$ Program Studi SI Gizi, STIKES Salewangang, Maros
}

Diterima: 13 Maret 2019; Revisi: 30 Juli 2019; Diterbitkan: 30 Juli 2019

\begin{abstract}
Background: Breast milk is the best food for babies, but exclusive breastfeeding coverage is still not in accordance with national target standards (minimum 80\%). Objective: To determine the characteristics and knowledge of postpartum mothers about early breastfeeding initiation. Method: Descriptive study with 29 postpartum mothers in the Mandiri Basri Independent Practice Midwife in 2018. The technique of sample collection was done by means of Total Sampling. Data collection was carried out by filling out a structured questionnaire to the respondents. The research instruments consisted of 15 questions in the form of multiplechoice. Results: Characteristics of postpartum mothers are the highest age of 30-33 years $(27.6 \%)$, education namely high school group (48.3\%), working as housewife $(93.1 \%)$, and number of children namely 1 child $(55.2 \%)$. Knowledge of postpartum mothers about Early Breastfeeding Initiation (IMD) was mostly categorized as still lacking (55.17\%). Conclusion: Age of postpartum mothers aged $>30$ years with education included in the high category and working as a housewife and knowledge of postpartum mothers about Early Breastfeeding Initiation (IMD) were mostly categorized as lacking
\end{abstract}

Keywords: Initiation of Early Breastfeeding, Knowledge, Characteristics of Postpartum Mothers

\section{Abstrak}

Latar Belakang: ASI merupakan makanan yang terbaik untuk bayi namun cakupan ASI eksklusif masih tidak sesuai dengan standar target nasional (minimal 80\%). Tujuan: Untuk mengetahui karakteristik dan pengetahuan ibu nifas tentang inisiasi menyusu dini. Metode: Penelitian deskriptif dengan populasi ibu nifas berjumlah 29 orang di Bidan Praktek Mandiri Murni Basri pada tahun 2018. Teknik pengumpulan sampel dilakukan dengan cara Total Sampling. Pengumpulan data dilakukan dengan pengisian kuesioner secara terstruktur kepada responden.Instrumen penelitian terdiri dari 15 pertanyaan berbentuk multiplechoice. Hasil: Karakteristik Ibu nifas yaitu umur yang tertinggi yaitu 3033 tahun (27,6\%), pendidikan yaitu kelompok pendidikan SMA/(48,3\%), pekerjaan sebagai IRT/Tidak bekerja $(93,1 \%)$, dan jumlah anak yaitu 1 anak $(55,2 \%)$. Pengetahuan ibu nifas tentang Inisiasi Menyusu Dini (IMD) sebagian besar dikategorikan masih kurang(55,17\%). Kesimpulan: Secara umur ibu nifas sudah berumur $>30$ tahun dengan pendidikan termasuk kategori tinggi dan bekerja sebagai ibu rumah tangga serta pengetahuan ibu nifas tentang Inisiasi Menyusu Dini (IMD) sebagian besar dikategorikan masih kurang.

Kata Kunci: Inisiasi Menyusu Dini, Pengetahuan, Karakteristik Ibu Nifas.

*Korespondensi: Kurnia, Email : nhyay@yahoo.com

DOI : $10.22487 / \mathrm{j} 26227622.2019 . v 3.11 .12118$

\section{PENDAHULUAN}

Pemberian Air Susu Ibu (ASI) atau menyusui bayi dilakukan berbagai lapisan masyarakat di seluruh dunia, karena banyak manfaatnya yang diperoleh dari ASI Eksklusif dan praktik menyusui selama 2 tahun. Pemberian Inisiasi Menyusu Dini merupakan cara pemberian makanan sangat tepat dan kesempatan terbaik bagi kelangsungan hidup bayi di usia 6 bulan, dan melanjutkan pemberian ASI sampai umur 2 tahun (Hailemariam, Adeba, \& Sufa, 2015).

WHO (World Health Organization) mengeluarkan standar pertumbuhan anak yang kemudian diterapkan di seluruh dunia yang isinya adalah, menekankan pentingnya pemberian ASI saja kepada bayi sejak lahir sampai usia 6 bulan. Setelah itu, barulah bayi di berikan makanan pendamping ASI sambil tetap disusui hingga usia mencapai 2 tahun (WHO, 2011).

Sejalan dengan peraturan yang ditetapkan oleh WHO, di Indonesia juga menerapkan peraturan terkait pentingnya Asi Eksklusif yaitu dengan mengeluarkan Peraturan Pemerintah (PP) Nomor 33/2012 tentang pemberian Inisiasi Menyusu Dini (Republik Indonesia, 2012). Peraturan ini menyatakan kewajiban ibu untuk menyusui bayinya sejak lahir sampai bayi berusia 6 bulan.

Meskipun menyusui dan ASI sangat bermanfaat, namun belum terlaksana sepenuhnya, diperkirakan $85 \%$ ibu - ibu di dunia tidak mem- 
berikan ASI secara optimal. Menurut data Riskesdas Indonesia pada tahun 2007-2013 terjadinya fluktuasi prevalensi pemberian ASI eksklusif dari $32 \%$ menurun ke15,3\% dan di tahun 2013 meningkat pada angka 30,2\%(Kemenkes RI, 2013). Beberapa hasil penelitian menunjukkan bahwa persentase praktek IMD masih sangat rendah dan pemberian ASI eksklusif masih rendah sebagian besar responden memiliki peran keluarga yang kurang baik. (Mia Destyana, Angkasa, \& Nuzrina, 2018; Takahashi et al., 2017). Berdasarkan permasalahan penelitian yaitu masih rendahnya pemberian ASI Eksklusif dan praktek IMD maka penelitian ini bertujuan untuk menganalisis karakteristik dan pengetahuan ibu nifas tentang IMD.

\section{BAHAN DAN METODE}

Penelitian ini adalah penelitian deskriptif yaitu suatu penelitian yang menggambarkan bagaimana pengetahuan ibu nifas tentang Inisiasi Menyusu Dini (IMD) di Bidan Praktek Mandiri Murni Basri Kabupaten Maros. Populasi penelitian adalah semua ibu nifas yang pernah melahirkan di Bidan Praktek Mandiri Murni Basri sebanyak 29 orang. Pengumpulan data diperoleh langsung dari responden dengan teknik wawancara secara terstruktur menggunakan instrumen kuesioner berupa 15 pertanyaan dalam bentuk multiplechoice yang mengukur pengetahuan ibu tentang Inisiasi Menyusu Dini (IMD).

\section{HASIL}

Tabel 1 menunjukkan bahwa sebagian besar responden berumur 30-33 tahun(27,6\%) dan umur 34-37 tahun $(10,3 \%)$, pendidikan SMA/Sederajat sebesar $48,3 \%$, Adapun pekerjaan responden yaitu sebagai IRT/Tidak bekerja sebanyak 27 orang $(93,1 \%)$ dan jumlah anak yaitu kelompok jumlah anak 1 sebanyak 16 orang $(55,2 \%)$. Tabel 2 menunjukkan bahwa sebagain besar ibu nifas memiliki pengetahuan yang kurang tentang inisiasi menyusu dini yaitu sebesar $55,17 \%$ dan kategori baik hanya $13,80 \%$.

\section{PEMBAHASAN}

Secara keseluruhan, hasil penelitian menunjukkan bahwa ibu nifas sebagian besar masih memiliki pengetahuan yang kurang tentang Inisiasi Menyusu Dini (IMD) $(55,17 \%)$. Dari 3 aspek penilaian tentang pengetahuan ibu nifas, manfaat dan kandungan ASI hampir sebagian besar responden menjawab dengan kurang tepat. Hal tersebut membuktikan bahwa pengetahuan ibu nifas tentang manfaat dan kandungan ASI masih sangat rendah. Terutama kandungan kolostrum yang terdapat pada hari pertama ASI keluar. ASI mengandung kolostrum yang sangat diperlukan bayi dalam tumbuh kembangnya. Dengan memberikan susu pertama yang mengandung kolostrum, diharapkan bayi mampu melampaui tahun pertamanya dari penyakit yang dapat menyebabkan penurunan kesehatan (Sari,

Tabel 1. Karakteristik Responden

\begin{tabular}{|c|c|c|}
\hline Karakteristik Subjek Penelitian & $\mathbf{n}$ & $\%$ \\
\hline \multicolumn{3}{|l|}{ Umur } \\
\hline $18-21$ & 6 & 20,7 \\
\hline $22-25$ & 6 & 20,7 \\
\hline $26-29$ & 6 & 20,7 \\
\hline $30-33$ & 8 & 27,6 \\
\hline 34-37 & 3 & 10,3 \\
\hline \multicolumn{3}{|l|}{ Pendidikan } \\
\hline SD & 2 & 6,9 \\
\hline SMP/Sederajat & 12 & 41,4 \\
\hline SMA/Sederajat & 14 & 48,3 \\
\hline D3 & 1 & 3,4 \\
\hline \multicolumn{3}{|l|}{ Pekerjaan } \\
\hline IRT/Tidak Bekerja & 27 & 93,1 \\
\hline Wiraswasta & 1 & 3,4 \\
\hline PNS & 1 & 3,4 \\
\hline \multicolumn{3}{|l|}{ Suku } \\
\hline Makassar & 14 & 48,3 \\
\hline Bugis & 15 & 51,7 \\
\hline \multicolumn{3}{|l|}{ Jumlah Anak } \\
\hline 0 & 7 & 24,1 \\
\hline 1 & 16 & 55,2 \\
\hline 2 & 1 & 3,4 \\
\hline 3 & 4 & 13,8 \\
\hline
\end{tabular}

Tabel 2. Pengetahuan Ibu Nifas tentang Inisiasi Menyusu Dini (IMD)

\begin{tabular}{lcc}
\hline Pengetahuan IMD & $\mathbf{n}$ & $\mathbf{\%}$ \\
\hline Baik & 4 & 13,8 \\
Cukup & 9 & 31,03 \\
Kurang & 16 & 55,17 \\
Total & $\mathbf{2 9}$ & $\mathbf{1 0 0}$ \\
\hline
\end{tabular}


2012). Namun, beberapa faktor yang menghambat ibu nifas memberikan kolostrum dengan segera diantaranya ibu merasa kelelahan untuk menyusui setelah melahirkan, kolostrum tidak keluar atau jumlahnya tidak memadai, bahkan kolostrum dibuang karena dianggap kotor/basi dan berbahaya bagi bayiHal tersebut tidak akan terjadi jika seorang ibu nifas mempunyai pengetahuan yang baik serta mendapat dukungan dari keluarga tentang pentingnya ASI eksklusif (Roesli, 2008). Penelitian lainnnya juga menunjukkan bahwa 5 orangdari 11 responden ternyata tidak mengetahui tentang kolostrum yang terkandung pada ASI eksklusif dan tidakmemberikannya kepada bayinya saat pertama setelah melahirkan (Astuti, Yugistyowati, \& Maharani, 2015).

Menurut ibu pemberian tidak dilakukan karena tidak mengetahui manfaat dari kolostrum tersebut. pengetahuan tentang Inisiasi Menyusu Dini (IMD) yang kurang oleh ibu disebabkan karena informasi yang didapatkan oleh responden sedikit tentang Inisiasi Menyusu Dini (IMD), responden hanya mendapatkan informasi tersebutdari bidan dan kader saja saat posyandu dimana informasi yang disampaikan dengan cara lisan,sehingga pengetahuan yang dimiliki responden kurang terutama informasi tentang Inisiasi Menyusu Dini (IMD) yangmeliputi pengertian, manfaat,dan cara pemberian ASI eksklusif (Mastuti, Mega, Masruroh, \& Isfaizah, 2015). Tingkat pengetahuan ibu yang baik tidak saja karena ibu berpendidikan tinggi tetapi juga dipengaruhi oleh informasi beragam yangtelah diperoleh ibu (Prasetya, 2007).

Pengetahuan yang baik tentang ASI dan IMD dapat meningkatkan praktek IMD dan pemberian ASI hingga usia 6 bulan. Penelitian lainnya menunjukkan bahwa terdapat hubungan yang bermakna antara pengetahuan ibu dengan pemberian ASI secara eksklusif $(p=0,000)$, dan IMD dengan pemberian ASI secara eksklusif $(p=0,025)$ (Rosyid \& Sumarmi, 2017). Dukungan petugas kesehatan juga berperan penting dalam pelaksanaan IMD. Dukungan tenaga kesehatan terlihat dari upaya tenaga kesehatan untuk menginformasikan tata laksana dan manfaat IMD, serta mendampingi ibu saat proses IMD dilakukan (Sihombing \& Rizkianti, 2016). Petugas kesehatan yang terampil di fasilitas kesehatan memiliki korelasi yang positif dengan praktek menyusui yang baik (Oakley, Benova, Macleod, Lynch, \& Campbell, 2018). Upaya untuk mendorong ibu dan masyarakat untuk menyusui secara eksklusif merupakan bagian dari strategi kesehatan masyarakat primer untuk mencegah penghentian menyusui dini (Yilmaz et al., 2017).

\section{KESIMPULAN}

Pengetahuan ibu nifas tentang Inisiasi Menyusu Dini (IMD) sebagian besar dikategorikan masih kurang khususnya aspek manfaat dan kandungan ASI hampir sebagian besar responden menjawab dengan salah. Oleh karena itu,diperlukan suatu upaya untuk meningkatkan pengetahuan dan pemahaman ibu dan keluarga tentang pentingnya IMD melalui penyuluhan dan konseling laktasi ibu.

\section{DAFTAR PUSTAKA}

Astuti, D., Yugistyowati, A., \& Maharani, O. (2015). Tingkat Pengetahuan Ibu Nifas tentang Ko- lostrum dengan Motivasi Pemberian Kolostrum di Rumah Sakit Panembahan Senopati Bantul,Yogyakarta. Jurnal Ners Dan Kebidanan Indonesia, 3(3), 156-161. https:// doi.org/10.21927 jnki.2015.3(3).156-161

Hailemariam, T. W., Adeba, E., \& Sufa, A. (2015). Predictors of early breastfeeding initiation among mothers of children under 24 months of age in rural part of West Ethiopia. BMC Public Health, 15. https://doi.org/10.1186/s12889-015 $-2420-\mathrm{z}$

Kemenkes RI. (2013). Riset Kesehatah Dasar Tahun 2013. Badan Penelitian dan Pengembangan Kesehatan Departemen Kesehatan Republik Indonesia.

Mastuti, Mega, Masruroh, \& Isfaizah. (2015). Gambaran Pengetahuan Ibu tentang Pemberian Asi Eksklusif di Wilayah Kerja Puskesmas Ungaran Kabupaten Semarang (Thesis). STIKES Ngudi Waluyo, Semarang.

Mia Destyana, R., Angkasa, D., \& Nuzrina, R. (2018). Hubungan Peran Keluarga dan Pengetahuan Ibu Terhadap Pemberian ASI di Desa Tanah Merah Kabupaten Tangerang. Indonesian Journal of Human Nutrition, 5(1), 41-50. https://doi.org/10.21776/ub.ijhn.2018.005.01.5

Oakley, L., Benova, L., Macleod, D., Lynch, C. A., \& Campbell, O. M. R. (2018). Early breastfeeding practices: Descriptive analysis of recent Demo graphic and Health Surveys. Maternal \& Child Nutrition, 14(2). https:// doi.org/10.1111/ mcn.12535

Prasetya. (2007). Metodologi Penelitian Kuantitatif. Jakarta: PT Raja Grafindo Persada.

Republik Indonesia. (2012). Peraturan Pemerintah Republik Indonesia Nomor 33 Tahun 2012 Tentang Pemberian Air Susu Ibu Eksklusif. Kementerian Hukum dan Hak Asasi Manusia.

Roesli, U. (2008). Inisiasi Menyusui Dini Plus ASI Eksklusif. Jakarta: Pustaka Bunda.

Rosyid, Z. N., \& Sumarmi, S. (2017). Hubungan Antara Pengetahuan Ibu dan IMD Dengan Praktik ASI Eksklusif. Amerta Nutrition, 1(4), 406-414. https://doi.org/10.20473/ amnt.v1i4.2017.406-414

Sari, N. D. K. (2012). Motivasi Bidan Desa dalam Pelaksanaan Program Asi Eksklusif di Puskesmas Bergas, Kabupaten Semarang. Jurnal Kesehatan Masyarakat Universitas Diponegoro, 1(2). Retrieved from https:// www.neliti.com/id/publications/18735/ motivasi-bidan-desa-dalam-pelaksanaanprogram-asi-eksklusif-di-puskesmas bergas

Sihombing, N. M., \& Rizkianti, A. (2016). Dukungan Tenaga Kesehatan Terhadap Pelaksanaan Imd: Studi Kasus Di Rs Swasta X Dan Rsud Y Di Jakarta. Jurnal Kesehatan Reproduksi, 7(2), 95 - 108-108. https://doi.org/10.22435/ kespro.v7i2.5238.95-108

Takahashi, K., Ganchimeg, T., Ota, E., Vogel, J. P., Souza, J. P., Laopaiboon, M., ... Mori, R. (2017). Prevalence of early initiation of breastfeeding and determinants of delayed initiation of breastfeeding: Secondary analysis of the 
WHO Global Survey. Scientific Reports, 7. https://doi.org/10.1038/srep44868

WHO. (2011). Exclusive breastfeeding for six months best for babies everywhere. Retrieved 29 July 2019, from https://www.who.int/mediacentre/ news/statements/2011 breastfeeding

Yılmaz, E., Doğa Öcal, F., Vural Yılmaz, Z., Ceyhan, M., Kara, O. F., \& Küçüközkan, T. (2017). Early initiation and exclusive breastfeeding: Factors influencing the attitudes of mothers who gave birth in a babyfriendly hospital. Turkish Journal of Obstetrics and Gynecology, 14(1), 1-9. https:// doi.org/10.4274/tjod.90018 